\title{
Effects of bariatric surgery on psychological well-being among adolescents: a case series study from Turkey
}

\author{
Mazlum ÇÖPÜR, ${ }^{1}$ Nilüfer SAATÇIOĞLU TINKIR, ${ }^{2}$ Sidar ÇÖPÜR ${ }^{3}$
}

\begin{abstract}
Objective: Our aim is to determine the psychiatric outcomes of bariatric surgery among adolescent patients with obesity, a condition with high psychiatric comorbidity rates. Methods: Psychiatric evaluation of the patients includes Beck Depression Inventory, Beck Anxiety Inventory, Eating Attitudes Test and World Health Organization Quality of Life questionnaire (WHOQOL-BREF) prior to surgery and at post-operative year. Results: Adolescent patients admitting for bariatric surgery have high rates of psychiatric comorbidities. We report significant improvement in psychological well-being of the adolescent patients following sleeve gastrectomy procedure including depression, anxiety and feeding behavior scores and quality of life. Discussion: Limited number of studies regarding the psychiatric outcomes of bariatric surgery on adolescent patients are present in the literature. Improvement in depression and quality of life scores have also been reported in previous studies, whereas, no comprehensive study on anxiety and feeding behavior scores, to our knowledge, had been performed. Therefore, our case series study is significant by demonstrating the psychiatric outcomes of bariatric surgery more thoroughly. In addition, higher reductions in BMI have been observed following sleeve gastrectomy procedure compared to the findings in the literature mostly including roux-en-Y gastric bypass procedure in adults. We propose that psychiatric comorbidities of the adolescent patients should be more prominent determinant of decision making procedure for bariatric surgery. (Anatolian Journal of Psychiatry 2020; 21(5):544-548)
\end{abstract}

Keywords: adolescent, bariatric surgery, depression, anxiety, psychiatry

\section{Bariyatrik cerrahinin ergenlerde ruhsal durum üzerine etkileri: Türkiye'den bir olgu serisi çalışması}

öz

Amaç: Bu çalışmada ergenlik çağındaki obezite hastalarında bariyatrik cerrahinin psikiyatrik sonuçlarını belirlemeyi amaçladık. Yöntem: Hastaların psikiyatrik değerlendirme süreci Beck Depresyon Ölçeği, Beck Anksiyete Ölçeği, Yeme Tutumu Testi ve Dünya Sağlık Örgütü Yaşam Kalitesi Ölçeğini (WHOQOL-BREF) içermektedir. Değerlendirme ameliyat öncesi dönemde ve ameliyat sonrasında 1. yıl takibinde yapılmıştır. Sonuçlar: Bariyatrik cerrahi amacıyla kliniğe başvuran ergenlik dönemi hastalarında eşlik eden psikiyatrik bozukluklar sık görülmektedir. Çalışmamızın sonucunda tüp mide ameliyatı sonrasında hastaların ruhsal durumlarında depresyon, anksiyete, yeme tutumu ve yaşam kalitesi ölçekleri de dahil olmak üzere önemli oranda iyileşme olduğunu gözledik. Tartışma: Bariyatrik cerrahinin psikiyatrik sonuçlarıyla ilişkili alan yazında az sayıda çalışma vardır. Depresyon ve yaşam kalitesi ölçeklerinde gözlemlediğimiz iyileşmeler önceki çalışmalarla uyumlu olup hastaların anksiyete ve yeme tutumlarındaki değişimleri inceleyen kapsamlı bir çalışma yoktur. Çalışmamız ergenlik döneminde bariyatrik cerrahi müdahale geçiren hastaların psikiyatrik durumlarını daha ayrıntılı incelemesi bakımından önemlidir. Ayrıca çalışma-

\footnotetext{
${ }^{1}$ Professor in Child and Adolescence Psychiatry, Arel Univ. Faculty of Science Department of Psychology, İstanbul, Turkey

${ }^{2}$ Post-graduate student, İstanbul Arel University, Department of Psychology, İstanbul, Turkey

${ }^{3} \mathrm{Mr}$, Koç University School of Medicine, İstanbul, Turkey

Correspondence address I Yazışma adresi:

Mazlum ÇÖPÜR, MD, Prof., Arel University Faculty of Science Department of Psychology, İstanbul, Turkey

E-mail: sidar1996@yahoo.com.tr

Received: November $23^{\text {rd }}, 2019$, Accepted: January $07^{\text {th }}, 2020$, doi: 10.5455/apd.74071
}

Anatolian Journal of Psychiatry 2020; 21(5):544-548 
mızda tüp mide ameliyatı sonucunda ergenlik dönemi hastalarımızda beden kitle indeksinde alan yazında çoğunlukla yetişkin hastalarda yapılan roux-en-Y gastrik baypass ameliyatı sonucunda bildirilenden daha yüksek miktarda bir iyileşme görmekteyiz. Ergenlik dönemi hastalarında hastaların eşlik eden psikiyatrik bozukluklarının bariyatrik cerrahi kararı alınırken, kararın daha önemli bir parçası olmasını önermekteyiz. (Anadolu Psikiyatri Derg 2020; 21(5):544-548)

Anahtar sözcükler: Ergenlik, bariyatrik cerrahi, depresyon, anksiyete, psikiyatri

\section{INTRODUCTION}

An epidemic of current medical era, childhood obesity, with an estimated prevalence of $18.5 \%$ has various comorbidities including type II diabetes mellitus, dyslipidemia, hypertension, obstructive sleep apnea, non-alcoholic fatty liver disease, pseudotumor cerebri and psychiatric conditions. ${ }^{1,2}$ Behavioral therapy as dietary regulations and physical activity is preferred as first line treatment while pharmacotherapy such as orlistat and metformin are included if first line of treatment becomes ineffective. Despite being present at most guidelines; bariatric surgery is rarely preferred in patients under age 18 as it composes only $1 \%$ of all bariatric surgeries. ${ }^{3}$ However, rates of surgical intervention at pediatric age group rises exponentially over the last decades despite the lack of large scale randomized studies regarding the efficiency and safety. ${ }^{3,4}$

Common adverse effects of surgical intervenetion in obesity are malnutrition, wound infections, post-operative bleeding, hiatal hernia, embolism, intestinal obstruction and micronutrient deficiency. ${ }^{4}$ Post-operative depression or worsening of depressive status and suicidal intentions have also been reported. In addition, comorbid psychiatric conditions, especially eating disorders, and predominant etiologies of childhood obesity such as genetic, endocrinological and intrauterine factors are considered as negative predictors of success in bariatric surgery. ${ }^{5}$ Therefore, multidisciplinary approach to childhood obesity is the basis of every treatment guideline. Eligibility criteria for bariatric surgery is as same as adult population, whereas, lack of consensus for age limitation is apparent among guidelines. However, bariatric surgery had been performed on pediatric patients as young as 5 years old. ${ }^{6}$

Most common psychiatric comorbidities include depression, anxiety and eating disorders while use of psychiatric medications such as anti-depressant and anxiolytic drugs is common among obese adolescents. ${ }^{3-6}$ Although it has been considered as a minor eligibility criterion for bariatric surgery with lower prevalence rates compared to most organic comorbidities, psychiatric comorbidities are one of the major factors in the deci- sion making process. ${ }^{7}$ In this study, we report the effect of surgical intervention on psychological well-being of 4 adolescent patient suffering from obesity from a bariatric surgery center in Turkey.

\section{METHODS}

Prior to the study approval from Ethics Committee was obtained. Participants were recruited from a bariatric clinic performing high numbers of bariatric surgery per year in Turkey. Informed consent of the patients were obtained. Psychiatric evaluation of the patients prior to surgery and at 1-year follow-up include Beck Depression Inventory, Beck Anxiety Inventory, Eating Attitudes Test and World Health Organization Quality of Life questionnaire (WHOQOL-BREF).

WHOQOL-BREF, developed in $1998^{8}$ and validated for Turkish population in $1999,{ }^{9}$ is a questionnaire composed of 26 questions designed to assess the quality of life of an individual through four subcategories as physical health, psychological health, social relationships, and environment. Score of 14 is considered as a standard score while scores higher than 14 are considered as high quality of life in those subcategories.

Beck Depression Inventory (BDI), a questionnaire with twenty-one 3-point Likert scale questions to evaluate the characteristic features and symptoms of depression, was developed in $1961^{10}$ and validated for Turkish population in 2005. ${ }^{11}$ Assessment of the individuals with BDI may reveal no depression (BDI $\leq 9$ ), mild depression $(10 \leq \mathrm{BDI} \leq 15)$, moderate depression $(16 \leq \mathrm{BDI} \leq 23)$, and severe depression (BDI $>23$ ).

A questionnaire composed of twenty-one 3-point Likert scale questions, Beck Anxiety Inventory, is used to evaluate the characteristic features of anxiety in individuals. It is developed in 1998 by Beck et al. ${ }^{12}$ and validated for Turkish population in 1998. ${ }^{13}$ Assessment of the individuals may reveal no anxiety (BAI $\leq 15)$, minimal anxiety $(16 \leq \mathrm{BAl} \leq 22)$, moderate anxiety ( $23 \leq \mathrm{BAI} \leq 42)$ and severe anxiety (BAl >42).

Eating Attitudes Test, developed in 1979 by Garfield and Garfinkel, ${ }^{14}$ is a test with forty 6- point 
Likert questions commonly used to evaluate troubled eating behaviors of individuals. It has been validated for Turkish population in 1989 by Savaşır and Erol. ${ }^{15}$ Scores above 30 indicate troubled eating behavior.

\section{CASE PRESENTATIONS}

\section{CASE 1}

Sixteen-year-old female patient was presented to bariatrics clinic with BMI of $37.45 \mathrm{~kg} / \mathrm{m}^{2}$ (height: $162 \mathrm{~cm}$, weight: $99 \mathrm{~kg}$ ). Psychiatric history of the patient was significant for insomnia, severe podophobia triggered even with brief periods of visualization of feet, and aviophobia (phobia of airplanes) for two years. Social Isolation and distance to school were present with an average academic performance. She had been routinely followed-up by a child and adolescent psychiatrist and prescribed with fluoxe-tine. Presurgical evaluation of the patient demonstrated high eating behavior score and signs for depression and anxiety with low quality of life. Desire for surgery was originating from the patient. Primary complaint of the patient was social isolation and suicide threats towards parents. Further psychiatric evaluation of the patient showed no actual suicidal intentions and considered suicide threats as a mechanism to prevent her parents from discouraging her about the surgery. Patient underwent sleeve gastrectomy procedure after approval from the multidisciplinary council consisting of endocrinology, internal medicine, psychiatry and bariatric surgery specialists. Following the surgery fluoxetine treatment was discontinued and psychoeducation program was initiated for a year. At one-year follow-up patient had a BMI of 25.77 with improved psychological status. In addition, improvement in the feeding behavior, social relationship, psychological and physical health score had been recorded (Table 1 ).

Table 1. Body-mass index and psychiatric evaluation results of the patients before sleeve gastrectomy and at 1 year follow-up

\begin{tabular}{|c|c|c|c|c|c|c|c|c|}
\hline \multirow{2}{*}{$\begin{array}{l}\text { Cases } \\
\text { Features }\end{array}$} & \multicolumn{2}{|c|}{ Case 1} & \multicolumn{2}{|c|}{ Case 2} & \multicolumn{2}{|c|}{ Case 3} & \multicolumn{2}{|c|}{ Case 4} \\
\hline & $\begin{array}{l}\text { Before } \\
\text { surgery }\end{array}$ & $\begin{array}{l}\text { At 1-year } \\
\text { follow-up }\end{array}$ & $\begin{array}{l}\text { Before } \\
\text { surgery }\end{array}$ & $\begin{array}{l}\text { At 1-year } \\
\text { follow-up }\end{array}$ & $\begin{array}{l}\text { Before } \\
\text { surgery }\end{array}$ & $\begin{array}{l}\text { At 1-year } \\
\text { follow-up }\end{array}$ & $\begin{array}{l}\text { Before } \\
\text { surgery }\end{array}$ & $\begin{array}{l}\text { At 1-year } \\
\text { follow-up }\end{array}$ \\
\hline General features (age, gender) & 16 , fer & male & 17, fer & nale & $15, \mathrm{me}$ & ale & $15, \mathrm{~m}$ & nale \\
\hline $\mathrm{BMI}\left(\mathrm{kg} / \mathrm{m}^{2}\right)$ & 37.45 & 25.77 & 44.98 & 26.70 & 56.63 & 29.40 & 53.06 & 34.61 \\
\hline Eating Attitudes score & 38 & 12 & 32 & 19 & 45 & 16 & 52 & 22 \\
\hline Beck Depression Inventory & 27 & 10 & 26 & 17 & 28 & 10 & 27 & 14 \\
\hline Beck Anxiety Inventory & 21 & 6 & 16 & 11 & 19 & 8 & 18 & 12 \\
\hline General health score & 4 & 9 & 3 & 6 & 5 & 8 & 6 & 8 \\
\hline Physical health score & 17 & 27 & 10 & 20 & 23 & 25 & 16 & 23 \\
\hline Psychological health score & 14 & 23 & 13 & 18 & 13 & 21 & 15 & 18 \\
\hline Social relationships score & 6 & 12 & 5 & 11 & 12 & 13 & 10 & 12 \\
\hline Environmental health score & 26 & 30 & 17 & 30 & 28 & 31 & 20 & 30 \\
\hline
\end{tabular}

\section{CASE 2-4}

Seventeen-year-old female patient presented to bariatrics department with BMl of $44.45 \mathrm{~kg} / \mathrm{m}^{2}$ (height: $170 \mathrm{~cm}$, weight: $133 \mathrm{~kg}$ ). Psychiatric evaluation of the patient prior to surgery reveals high eating behavior and depression score with minimally high anxiety score. Quality of life was low (Case 2). She was routinely followed-up by a child and adolescent psychiatrists prior to bariatric surgery with no prescription.

Fifteen-year-old male patient presented to bariatrics clinic with BMI of $56.63 \mathrm{~kg} / \mathrm{m}^{2}$ (height: 165 $\mathrm{cm}$, weight: $154.2 \mathrm{~kg}$ ). Psychiatric evaluation performed prior to the surgery revealed high eating behavior and depression score with minimally elevated anxiety score (Case 3 ).

Fifteen-year-old male patient presented to bariatrics clinic with BMI of $53.06 \mathrm{~kg} / \mathrm{m}^{2}$ (height: $172 \mathrm{~cm}$, weight: $157 \mathrm{~kg}$ ). Psychiatric evaluation performed prior to the surgery revealed high eating behavior and depression score with minimally elevated anxiety score (Case 4).

Decision for bariatric surgery for case 2-4 were made by the multidisciplinary council consisting of endocrinology, internal medicine, psychiatry and bariatric surgery specialists. All patients were directly involved in the decision making 
process for the bariatric surgery. All three cases were considered as morbid obese (BMI>40 $\mathrm{kg} / \mathrm{m}^{2}$ ) while 1 of the patient was routinely followed-up by a child and adolescent psychiatrists. None of the cases were using any psychiatric medication. All patients underwent sleeve gastrectomy procedure and routine follow-up of the patients including BMI measurements and psychiatric evaluations were performed (Table 1). At one-year follow-up all patients had reduced depression and anxiety scores as well as improved quality of life. In addition, significant reduction in eating behavior score had been recorded.

\section{DISCUSSION}

Bariatric surgery emerges as a promising treatment modality for obesity, a global epidemic affecting over 1.4 billion adults and over 40 million children worldwide, over the last few decades. In addition to medical conditions including hypertension, cardiovascular events, dyslipidemia, obstructive sleep apnea and non-alcoholic fatty liver disease bariatric surgery candidates are at risk of comorbid psychiatric conditions. Most common psychiatric comorbidities include anxiety disorder (15-33\%), eating disorders (48-70\%) and depressive disorders (15-70\%). ${ }^{16}$ Studies in adult population highlighted pre-operative psychological well-being as a predictive factor in the treatment outcomes of bariatric surgery ${ }^{17}$ Anxiety, common psychiatric comorbidity, has negative impact on weight loss among adults. ${ }^{17} \mathrm{How}$ ever, studies investigating psychiatric outcomes of bariatric surgery in adolescents are limited.

A systematic review including 3-year follow-up of 950 children and adolescent obese patients demonstrate $13.3 \mathrm{~kg} / \mathrm{m}^{2}$ decrease in BMI while laparoscopic roux-en-Y gastric bypass (47.6\%) and adjustable gastric banding (27.8\%) are the most commonly preferred procedures. ${ }^{18}$ On the other hand, we report $18.91 \mathrm{~kg} / \mathrm{m}^{2}$ reduction in BMI (mean pre-op BMI=48.03, mean post-op $\mathrm{BMI}=29.12$ ) with sleeve gastrectomy procedure in a year. In contrast to literature findings of superiority of roux-en-Y gastric bypass over sleeve gastrectomy in adults in terms of decline in $\mathrm{BMI}$, our findings in a small study group indicates better weight loss with sleeve gastrictomy in adolescents. ${ }^{19,20}$ Beneficial effects of sleeve gastrectomy may be associated with decrease in the levels of ghrelin, an orexigenic molecule, or psychologically more adjustable state of adolescents compared to adults. Therefore, choice for bariatric procedure should be individualized as the age of patient being among the primary determinants. Furthermore, we report considerable increase in quality of life in adolescent patients after sleeve gastrectomy including elevated physical health score (mean pre-op $=16.5$, mean post-op=23.75), psychological health score (mean pre-op $=13.75$, mean post-op $=20$ ), social relationships score (mean pre-op $=8.25$, mean post-op=12) and environ-ment score (mean pre$\mathrm{op}=22.75$, mean post-op=30.25), concurrent with the literature. ${ }^{21}$

Beneficial effects of bariatric surgery on depressive symptoms have been reported in multiple studies while beneficial effects are transient in most cases by peaking at post-operative month 6 to 12 and regressing later on. ${ }^{22-25}$ Nevertheless, contradictory studies claiming no beneficial effect of bariatric surgery on depressive symptoms in adolescent patients who were evaluated twice before the operations are present in the literature. 26,27 Our findings suggest significant improvement in depressive symptoms (mean pre-op $\mathrm{BDI}=18.5$, mean post-op $\mathrm{BDI}=$ 9.25) with sleeve gastrectomy procedure in adolescents. In addition, it is important to note that one of our patient had discontinued antidepressant treatment in post-operative period. Limited numbers of studies in the literature regarding the efficiency of bariatric surgery on anxiety or eating disorders in adolescents remain inconclusive. Our findings suggest signi-ficant improvement in anxiety symptoms (mean pre-op BAl=27, mean post-op BAI=12.75) and eating attitudes score (mean pre-op score $=41.75$, mean post-op score=17.25).

To conclude, we report beneficial psychiatric effects of bariatric surgery in obese adolescents in terms of depressive symptoms and quality of life, concurrent with the literature, anxiety and eating disorder symptoms. In contrast to the literature, we observed better weight reduction with sleeve gastrectomy procedure in adolescents compared to other techniques preferred in adult studies. Our case series is significant by being the only study in adolescent patients investigating psychiatric effects of bariatric surgery in Turkey. We recommend consideration of psychological status of the patients as a valuable indication criterion at decision-making procedure for bariatric surgery. Our study is limited primarily due to low number of adolescent bariatric patients, thus, there is a clear need for more comprehensive studies. 
Authors' contributions: M.Ç.: design and coordination of the study, and writing of the manuscript; N.S.T.: coordination of the study, and data collection; S.Ç.: literature review, data collection and analysis, and writing of the manuscript.

\section{REFERENCES}

1. Skinner AC, Ravanbakht SN, Skelton JA, Perrin EM, Armstrong SC. Prevalence of obesity and severe obesity in US children, 1999-2016. Pediatrics 2018; 142(3): e20173459.

2. Cuda SE, Censani M. Pediatric obesity algorithm: a practical approach to obesity diagnosis and management. Front Pediatr 2019; 6:431.

3. Durkin N, Desai AP. What is the evidence for paediatric/ adolescent bariatric surgery? Curr Obes Rep 2017; 6(3):278-285

4. Treadwell JR, Sun F, Schoelles K. Systematic review and meta-analysis of bariatric surgery for pediatric obesity. Ann Surg 2008; 248(5):763-776.

5. Susmallian S, Nikiforova I, Azoulai S, Barnea R. Outcomes of bariatric surgery in patients with depression disorders. PLoS One 2019; 14(8): e0221576.

6. Mitchell F. Obesity: bariatric surgery in youth. Nat Rev Endocrinol 2012; 8(7):381.

7. Zeller MH, Roehrig HR, Modi AC, Daniels SR, Inge TE. Health-related quality of life and depressive symptoms in adolescents with extreme obesity presenting for bariatric surgery. Pediatrics 2006; 117:1155-1161.

8. Eser E, Fidaner H, Fidaner C, Eser SY, Elbi H, Göker E. WHOOOL-100 and WHOQOL-BREEF's psychometric features. 3P Magazine 1999, s.23-40.

9. The WHOQOL, Group 1998 Development of the World Health Organization WHOQOL-BREF quality of life assessment. Psychol Med 1998; 28:551-558.

10. Beck AT, Word CH, Mendelson M, Mock J, Erbaugh J. An inventory for measuring depression. Arch Gen Psychiatry 1961; 4:561-571.

11. Aktürk Z, Dağdeviren N, Türe M, Tuğlu C. Birinci Basamak için Beck Depresyon Tarama Ölçeği'nin Türkçe çeviriminin geçerlik ve güvenirliği. Turkish Journal of Family Practice 2005; 9(3):117-122.

12. Beck AT, Epstein N, Brown G, Steer RA. An inventory for measuring clinical anxiety: Psychometric properties. J Consult 1988; 56(6):893-897.

13. Ulusoy $M$, Sahin N, Erkman $H$. Turkish version of the beck anxiety inventor, psychometric proper ties. J Cog Psychother 1998; 12(2):28-35

14. Garner DM, Garfinkel PE. The Eating Attitudes: An index of the symptoms of anorexia nervosa. Psychol Med 1979; 9: 273-279.

15. Savaşır I. Erol N. Yeme tutum testi: anoreksiya nervoza belirtileri indeksi. Turk Psikiyatri Derg 1989; 7(23):19-25.

16. Herget S, Rudolph A, Hilbert A, Bluher S. Psycho-social status and mental health in adolescents before and after bariatric surgery. A systematic literature review. Appetite - London 2014; 76:208-208.
17. Brunault $P$, Jacobi $D$, Miknius $V$, Bourbao-Tournois $C$, Huten N, Gaillard P, et al. High pre-operative depression, phobic anxiety, and binge eating scores and low medium-term weight loss in sleeve gastrectomy obese patients: a preliminary cohort study. Psychosomatics 2012; 53:363-370.

18. Shoar S, Mahmoudzadeh H, Naderan M, Bagheri-Hariri S, Wong C, Parizi AS, et al. Long-term outcome of bariatric surgery in morbidly obese adolescents: a systematic review and meta-analysis of 950 patients with a minimum of 3 years follow-up. Obes Surg 2017; 27(12): 3110-3117.

19. Melissas J, Stavroulakis K, Tzikoulis V, Peristeri A, Papadakis JA, Pazouki A, et al. Sleeve gastrec-tomy vs roux-en-y gastric bypass. Data from IFSO-European chapter center of excellence program. Obes Surg 2017; 27(4):847-855.

20. Peterli R, Wölnerhanssen BK, Peters T, Vetter D, Kröll $D$, Borbely, et al. Effect of laparoscopic sleeve gastrectomy vs laparoscopic roux-en-y gastric bypass on weight loss in patients with morbid obesity: the SM-BOSS randomized clinical trial. JAMA 2018; 319(3):255-265.

21. Lindekilde $N$, Gladstone $B P$, Lübeck $M$, Nielsen J, Clausen $L$, Vach $W$, et al. The impact of bariatric surgery on quality of life: a systematic review and meta-analysis. Obes Rev 2015; 16(8):639-651.

22. Holterman $A X$, Browne $A$, Dillard BE, Tussing $L$, Gorodner V, Stahl C, et al. Short-term outcome in the first 10 morbidly obese adolescent patients in the FDA-approved trial for laparoscopic adjustable gastric banding. J Pediatr Gastroenterol Nutr 2007; 45:465-473.

23. Sysko R, Devlin MJ, Hildebrandt TB, Brewer SK, Zitsman JL, Walsh BT: Psychological outcomes and predictors of initial weight loss outcomes among severely obese adolescents receiving laparoscopic adjustable gastric banding. J Clin Psychiatry 2012; 73:1351-1357.

24. Zeller MH, Modi AC, Noll JG, Long JD, Inge TH. Psychosocial functioning improves following adolescent bariatric surgery. Obesity 2009; 17:985-990.

25. Zeller MH, Reiter-Purtill J, Ratcliff MB, Inge TH, Noll JG. Two-year trends in psychosocial functioning after adolescent Roux-en-Y gastric by-pass. Surg Obes Relat Dis 2011; 7:727-732.

26. Cozacov $Y$, Roy M, Moon S, Marin P, Menzo EL, Szomstein $S$, et al. Mid-term results of laparoscopic sleeve gastrectomy and Roux-en-Y gastric bypass in adolescent patients. Obes Surg 2014; 24:747-752.

27. Ratcliff MB, Reiter-Purtill J, Inge TH, Zeller MH: Changes in depressive symptoms among adolescent bariatric candidates from preoperative psychological evaluation to immediately before surgery. Surg Obes Relat Dis $2011 ; 7: 50-54$ 